\title{
PENGARUH MODEL PEMBELAJARAN KOOPERATIF TIPE GROUP INVESTIGATION TERHADAP PEMAHAMAN KONSEP MATEMATIS
}

\author{
R. Maisaroh Rezyekiyah Siregar \\ Winda Kartika Br Sembiring \\ maisarohsrg@gmail.com \\ windakartika@gmail.com \\ STKIP Budidaya Binjai
}

\begin{abstract}
ABSTRAK
Penelitian ini bertujuan untuk mengetahui apakah terdapat pengaruh model pembelajaran kooperatif tipe Group Investigation (GI) terhadap pemahaman konsep matematis. Penelitian ini dilaksanakan di SMK Swasta Abdi Negara Binjai Tahun Pelajaran 2018/2019. Metode yang digunakan dalam penelitian ini adalah eksperimen semu dengan design penelitian pretest posttest control group design. Teknik pengambilan sempel dalam penelitian ini adalah menggunakan teknik simple random sampling, dari teknik tersebut diambil 2 kelas yang akan dijadikan sempel, yaitu kelas X-TSM sebagai kelas eksperimen dan kelas X-AP sebagai kelas kontrol. Uji prasyarat yang digunakan adalah uji Liliefors untuk menguji normalitas data dan uji Fisher untuk menguji homogenitas data. Teknik analisis data dalam penelitian ini menggunakan uji regresi. Dengan demikian dapat disimpulkan terdapat pengaruh model pembelajaran kooperatif tipe Group Investigation (GI) terhadap pemahaman konsep matematis siswa di kelas X SMK Swasta Abdi Negara Binjai Tahun Pelajaran 2018/2019.
\end{abstract}

Kata Kunci : Pemahaman Konsep Matematis, Group Investigation (GI)

\section{PENDAHULUAN}

Dalam Undang-Undang Sistem Pendidikan Nasoinal No. 20 menyatakan bahwa tujuan pendidikan nasional adalah mencerdaskan kehidupan bangsa dan mengembangkan potensi peserta didik agar menjadi manusia yang bertaqwa terhadap Tuhan Yang Maha Esa, berakhlak mulia, berilmu, kreatif, sehat jasmani dan rohani, berkepribadian mantap dan mandiri, serta bertanggung jawab. Upaya dilakukan untuk mencapai pendidikan nasional adalah melalui pendidikan (Shoimin, 2014:20)

Pendidikan merupakan suatu kegiatan yeng bertujuan untuk mengubah cara berfikir dan tingkah laku kearah yang lebih baik. Dalam dunia pendidikan, matematika merupakan salah satu ilmu yang dipelajari pada setiap jenjang pendidikan. Matematika berfungsi mengembangkan kemampuan menghitung, mengukur, dan memecahkan masalah dalam kehidupan sehari-hari. Menurut Suherman (dalam Rusyda, dkk, 150:217) Matematika adalah pola pikir, pola mengorganisasikan, pembuktian yang logik, bahasa yang menggunakan istilah 
yang didefenisikan dengan cermat, jelas, dan akurat, representasinya dengan simbol dan padat, lebih berupa bahasa simbol mengenai ide daripada bunyi

Salah satu tujuan pembelajaran matematika dalam Depdiknas (2006) adalah agar peserta didik memiliki kemampuan memahami konsep matematika, menjelaskan keterkaitan antar konsep dan mengaplikasikan konsep atau algoritma secara luwes, akurat, efesien, dan tepat dalam pemecahan masalah.

Menurut Kusumawati (dalam Puspita, 2017:27) Pemahaman konsep matematis siswa merupakan salah satu kecakapan atau kemahiran matematika yang diharapkan dapat tercapai dalam belajar matematika yaitu dengan menunjukkan pemahaman konsep matematis yang dipelajarinya, menjelaskan keterkaitan antara konsep dan mengaplikasikan konsep secara luwes, akurat, efesien dan tepat. Adapun indikator yang menunjukkan pemahaman konsep diantaranya adalah: 1). Menyatakan ulang sebuag konsep, 2). Mengaplikasikan objek-objek menurut sifat-sifat tertentu, 3). Memberikan contoh dan bukan contoh dari konsep, 4). Menyajikan konsep dalam berbagai bentuk representasi matematika, 5). Mengembangkan syarat perlu atau syarat cukup suatu konsep, 6). Menggunakan, memanfaatkan dan memilih prosedur atau operasi tertentu, 7). Mengaplikasikan konsep atau algoritma pemecahan masalah (Puspita, 2017:27)

Berdasarkan indikator pemahaman konsep, Fakta di lapangan menunjukkan bahwa kemampuan pemahaman konsep siswa SMK Swasta Abdi Negara kelas X masih rendah. Hanya $10 \%$ siswa yang memiliki kategori pemahaman konsep tinggi, $20 \%$ siswa memiliki pemahaman konsep sedang, dan selebihnya berada pada kategori rendah.

Salah satu model pembelajaran yang berpusat pada siswa adalah model pembelajaran kooperatif. Menurut Nurhadi (dalam Azis, 2006: 95), Pembelajaran kooperatif adalah pendekatan pembelajaran yang berfokus pada penggunaan kelompok kecil untuk bekerjasama dalam memaksimalkan kondisi belajar untuk mencapai tujuan belajar. Dalam pembelajaran kooperatif, terdapat beberapa variasi model yang dapat diterapkan salah satunya adalah model model pembelajaran kooperatif tipe group investigation (GI) yang tidak hanya membantu siswa menumbuhkan kemampuan bekerjasama, berfikir kritis, dan 
mengembangkan sikap sosial siswa, tetapi juga membantu siswa memahami konsep-konsep.

Group investigation adalah model pembelajaran yang melibatkan siswa sejak perencanaan, baik menentukan topik maupun cara untuk mempelajarinya melalui investigation. Model pembelajaran ini mengajarkan siswa untuk memiliki kemampuan yang baik dalam berkomunikasi maupun dalam keterampilan proses kelompok (group process skils). Pada penelitian ini tahap-tahap pembelajaran kooperatif tipe group investigation dapat diaplikasikan dalam skala kondisi kelas yang luas yang dikemukakan oleh (Slavin, 2009) yaitu: Tahap 1: Mengidentifikasikan topik dan mengatur murid ke dalam kelompok, Tahap 2: Merencanakan tugas yang akan dipelajari, Tahap 3: Melaksanakan investigasi, Tahap 4: Menyiapkan laporan akhir, Tahap 5: Menperesentasikan laporan akhir, Tahap 6: Evaluasi.

\section{METODE}

Penelitian ini dilaksanakan di SMK Swasta Abdi Negara Binjai. Populasi dalam penelitian ini adalah seluruh kelas $\mathrm{X}$ semester ganjil tahun pelajaran 2018/2019 sebanyak 150 siswa yang berdistribusi dalam lima kelas. Sampel dari penelitian ini diambil melalui teknik sampel acak (random sampling). Sampel random sampling merupakan pengambilan anggota sampel dan populasi yang dilakukan secara acak tanpa memperhatikan strata yang ada dalam populasi. Dari lima kelas yang tersedia, sempel penelitian ini diambil sebanyak 2 kelas yaitu, kelas X-AP dan kelas X-TSM. Setelah itu, ditentukan kelas X-TSM sebagai kelas eksperimen yaitu kelas yang menggunakan model pembelajaran kooperatif tipe group investigation, dan kelas $\mathrm{X}$-AP sebagai kelas kontrol yaitu kelas yang mengunakan model pembelajaran konvensional.

Jenis penelitian ini adalah quasi eksperimen karena kondisi siswa tidak dapat dikontrol sepenuhnya. Menurut Sugiyono (2008), jenis penelitian quasi eksperimental design atau eksperimen semu ini memepunyai kelompok kontrol, tetapi tidak dapat berfungsi sepenuhnya untuk mengontrol variabel-variabel luar yang mempengaruhi pelaksanaan eksperimen. Desain penelitian yang digunakan 
dalam penelitian ini adalah pretest-posttets control group design. Rancangan dalam penelitian ini terdapat dua kelas yang dipilih secara acak, kemudian diberi pretest untuk mengetahui keadaan awal antara group investigation dan kelas kontrol menggunakan model pembelajaran konvensional.

Teknik pengumpuan data berupa tes. Tes tersebut berupa pretest-posttets yang berbentuk uraian. Dalam penelitian ini penulis menggunakan dua variabel, yakni variabel bebas $(\mathrm{X})$ dan veriabel terikat $(\mathrm{Y})$. Variabel bebas yaitu variabel yang mempengaruhi yang disimbolkan dengan $X$, dalam penelitian ini yang menjadi variabel bebas adalah model pembelajaran kooperatif tipe group investigation (GI). Variabel terikat yaitu variabel yang dipengaruhi yang disimbolkan dengan $\mathrm{Y}$, yang menjadi variabel terikat dalam penelitian ini adalah pemahaman konsep.

Analisis data yang digunakan dalam penelitian ini adalah uji normalitas, uji homogenitas, dan uji hipotesis. Adapun hasil perhitungannya adalah sebagai berikut :

Hasil Perhitungan Uji Normalitas Posttes

\begin{tabular}{|c|c|c|c|c|c|}
\hline Data & Kelompok & $\mathbf{L}_{\mathbf{0}}$ & $\mathbf{L}_{\mathbf{t}}$ & Kesimpulan & Ket \\
\hline \multirow{2}{*}{ Posttest } & Eksperimen & 0,042 & 0,161 & Terima $\mathrm{H}_{0}$ & Normal \\
\cline { 2 - 6 } & Kontrol & 0,004 & 0,161 & Terima $\mathrm{H}_{0}$ & Normal \\
\hline
\end{tabular}

Tabel di atas menunjukkan bahwa hasil perhitungan normalitas pretest pada kelas eksperimen dan kontrol yaitu data berdistribusi normal. Berdasarkan perhitungan dengan menggunakan uji Lilifors diperoleh hasil $\mathrm{L}_{0}$ pada kelas eksperimen adalah 0,042 sedangkan nilai $\mathrm{L}_{\mathrm{t}}$ adalah 0,161. Dengan demikian $\mathrm{L}_{0}<\mathrm{L}_{\mathrm{t}}$ ini berarti data berdistribusi normal. Begitu juga hasil $\mathrm{L}_{0}$ pada kelas kontrol adalah 0,004 sedangkan nilai $\mathrm{L}_{\mathrm{t}}$ adalah 0,161. Dengan demikian $\mathrm{L}_{0}<\mathrm{L}_{\mathrm{t}}$ ini berarti data berdistribusi normal.

Hasil Perhitungan Uji HomogenitasPosttest

\begin{tabular}{|c|c|c|c|c|}
\hline Data & Kelompok & $\mathbf{F}_{\text {hitung }}$ & $\mathbf{F}_{\text {tabel }}$ & Kesimpulan \\
\hline \multirow{2}{*}{ Pretest } & Eksperimen & \multirow{2}{*}{0,8873} & 1,9667 & Homogen \\
\cline { 2 - 2 } & Kontrol & & & \\
\hline
\end{tabular}


Tabel di atas menggambarkan bahwa hasil perhitungan homogenitas pretest menunjukan populasi penelitian ini homogen. Berdasarkan perhitungan dengan menggunakan uji Fisher diperoleh hasil $F_{\text {hitung }}$ pada kelas eksperimen adalah 0,8873 sedangkan nilai $F_{\text {tabel }}$ adalah 1,9667. Dengan demikian $F_{\text {hitung }}<F_{\text {tabel }}$ ini berarti $\mathrm{H}_{0}$ tidak ditolak, dengan demikian dapat disimpulkan bahwa populasi homogen.

\section{Analisis Regresi}

Model regresi linier antara variabel terikat Y (Data posttest) dengan variabel bebas X (Data Pretest) dinyatakan dalam Y $=\mathrm{a}+\mathrm{bX}$. Sehingga persamaan garis regresi adalah: $\mathrm{Y}=66,75+0,66 \mathrm{X}$

\section{HASIL DAN PEMBAHASAN}

Penelitian mengenai kemampuan pemahaman konsep matematis siswa, ini dilakukan di SMK Swasta Abdi Negara Binjai. Populasi dalam penelitian ini ialah seluruh siswa kelas X SMK Swasta Abdi Negara Binjai dan diperoleh sampel yaitu kelas X-TSM sebanyak 30 siswa sebagai kelas eksperimen yang diajarkan dengan menggunakan model pembelajaran Group Investigation (GI) dan kelas XAP sebanyak 30 siswa sebagai kelas kontrol yang diajarkan dengan model pembelajran Konvesional.

Sebelum memulai penelitian, peneliti membuat instrumen tes untuk mengukur kemampuan pemahaman konsep matematis siswa yang nantinya akan diberikan kepada kedua kelas. Instrumen tes ini terdiri dari 4 soal uraian. Setelah dilakukan uji coba instrumen, selanjutnya dilakukan uji validitas, uji reliabilitas, uji taraf kesukaran soal dan uji daya pembeda pada tiap butir soalnya. Soal yang valid ini peneliti gunakan sebagai tes untuk mengukur kemampuan pememahaman konsep matematis siswa pada kedua kelas tersebut. Berikut ini akan disajikan hasil pretest dan posttest pada kedua kelas tersebut.

\section{Data Hasil Pretes Kemampuan Pemahaman Konsep Matematis Siswa Kelas} Eksperimen dan Kelas Kontrol

Sebelum melaksanakan pembelajaran pada kedua kelas dengan pembelajaran yang berbeda yakni dengan model pembelajaran Group 
Investigation dan model pembelajaran konvesional,terlebih dahulu diadakan pretest untuk mengetahui kemampuan awal siswa khusunya kemampuan pemahaman konsep siswa dari kedua kelas tersebut. Untuk lebih jelasnya, data hasil tes kemampuan pemahaman konsep siswa kelas eksperimen dan kelas control.

Secara visual penyebaran data kemampuan pemahaman konsep matematis siswa kelas eksperimen yang menggunakan model pembelajarn Group Investigation dan kelas kontrol yang menggunakan model pembelajaran konvensional dapat dilihat pada histogram perbedaan nilai rata-rata, simpangan baku, dan varians pretest kelas eksperimen dan kelas kontrol sebagai berikut:

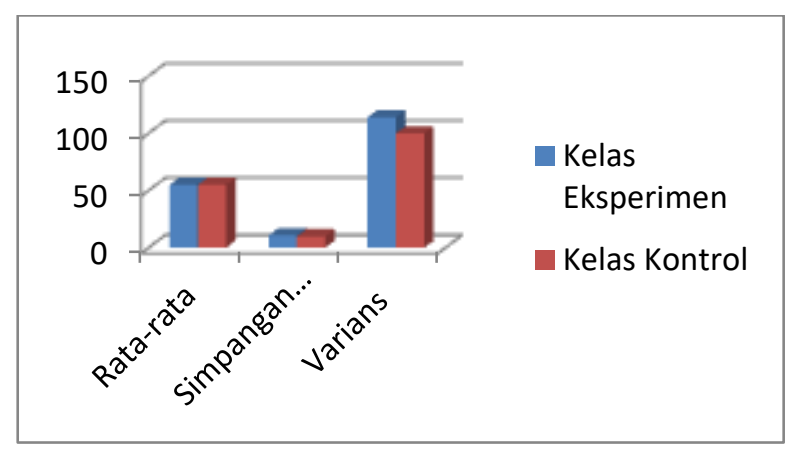

Gambar 1. Data Hasil Pretest

Data Hasil Posttest Kemampuan Pemecahan Masalah Matematika Siswa Kelas Eksperimen dan Kelas Kontrol

Setelah diberikan pretest pada kedua kelas, selanjutnya dilakukan pembelajaran yang berbeda yakni dikelas eksperimen dengan model Group Investigation dan model pembelajaran konvensional dikelas kontrol.

Secara visual penyebaran data kemampuan pemahaman konsep matematis siswa kelas eksperimen yang menggunakan model pembelajaran Group Investigation dan model pembelajaran konvensionl dikelas kontrol. dapat dilihat pada histogram perbedaan nilai rata-rata, simpangan baku, dan varians posttest kelas eksperimen dan kelas kontrol sebagai berikut: 


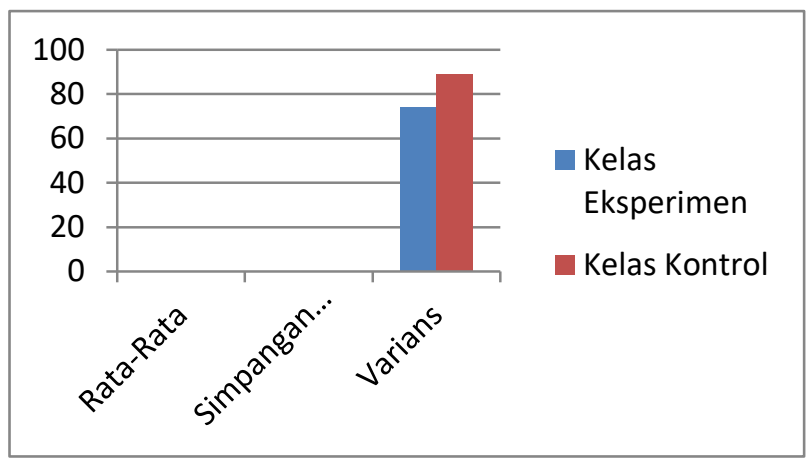

\section{Gambar 2. Data Hasil Postes}

Berdasarkan hasil pengamatan selama penelitian dengan menggunakan model pembelajaran Group Investigation pada kelas eksperimen, siswa memiliki antusias yang tinggi dalam belajar. Hal ini dapat terlihat dari bagaimana mereka menyelesaikan daftar pertanyaan, menyelesaikan soal-soal yang pada LAS dan juga mampu membuat kesimpulan. Selain itu siswa dapat menemukan masalah, berdiskusi dengan siswa yang lainnya dengan saling tanya jawab dan mampu memodelkan materi yang diajarkan.

Hasil dari pengujian hipotesis diperoleh bahwa 18,89470> 4,17087, maka $\mathrm{H}_{0}$ ditolak dan $\mathrm{H}_{\mathrm{a}}$ diterima sehingga arah koefisen cukup berarti . Sehingga kemampuan pemahaman konsep matematis siswa yang diajarkan dengan model pembelajaran Group Investigation berpengaruh terhadap kemampuan konsep matematis siswa.

\section{SIMPULAN}

Berdasarkan analisis data dan pembahasan maka diperoleh bahwa 18,89470> 4,17087maka $\mathrm{H}_{0}$ ditolak dan $\mathrm{H}_{\mathrm{a}}$ diterima sehingga arah koefisen cukup berarti, uji kelinieritas apabila $0,01667<5,79453$ maka $\mathrm{H}_{0}$ diterima dan $\mathrm{H}_{\mathrm{a}}$ ditolak maka linier, dan uji hipotesis apabila 5,771 > 1,708 maka $\mathrm{H}_{0}$ ditolak dan $\mathrm{H}_{\mathrm{a}}$ diterima. Sehingga dapat disimpulkan bahwa terdapat pengaruh model pembelajaran Group Investigation terhadap kemampuan pemahaman konsep matematis siswa kelas X SMK Swasta Abdi Negara Binjai tahun pelajaran 2018/2019. 


\section{DAFTAR PUSTAKA}

Azis, Abdul. dkk. Penerapan Model Pembelajaran Kooperatif Dengan Memanfaatkan Alat Peraga Sains Fisika untuk Meningkatkan Hasil dan Kerja Sama Siswa. Jurnal Pend. Fisika Indonesia: Vol. 4 No. 2. 2006

Dimyati dan Mudjiono, Belajar dan Pembelajaran. Jakarta: Rineka Cipta, 2013.

Puspita, Eka. 2017. Pengaruh Kemampuan Pemahaman Konsep Matematika Mahasiswa Melalui Metode Pembelajaran Learning Starst Whit A Question, Jurnal Mosharafa: Vol. 6 No. 1. 2017.

Rusyda, Nurul Afifa dan Sari, Septiani Dwi. 2017. Pengaruh Penerapan Contextual Teaching And Learning Terhadap Kemampuan Pemahaman Konsep Matematis Siswa SMP Pada Materi Garis Dan Sudut. Jurnal Pendidikan Matematika. No. 1. 2017.

Shoimin, Aris. 68 Model Pembelajaran Inovatif dalam Kurikulum 2013. Yogyakarta: Ar-Ruzz Media, 2014.

Sugiyono. Metode Penelitian Pendidikan. Bandung: Alfabeta, 2008. 